DOI: https://doi.org/10.32836/2521-666X/2021-71-12

УДК 336.131

Гончаренко Н.Г.

кандидат економічних наук, доцент,

Національна академія Національної гвардії України

\title{
Honcharenko Natalia
}

National Academy of the National Guard of Ukraine

\section{БУХГАЛТЕРСЬКИЙ ОБЛІК ЯК ЗАСІБ ЗАБЕЗПЕЧЕННЯ УПРАВЛІННЯ ФІНАНСАМИ БЮДЖЕТНИХ УСТАНОВ В УМОВАХ ПЕРЕХОДУ ДО МІЖНАРОДНИХ СТАНДАРТІВ - ТЕОРЕТИЧНИЙ АСПЕКТ}

\author{
ACCOUNTING AS A MEANS OF PROVIDING FINANCIAL MANAGEMENT \\ OF BUDGETARY INSTITUTIONS IN THE CONDITIONS OF TRANSITION \\ TO INTERNATIONAL STANDARDS - THEORETCHE THEORETCH
}

Під час організації діяльності бюджетних установ виникає необхідність у достовірному і своєчасному обліку руху коштів, які їм виділяються з державного бюджету. Це передбачає розроблення теоретико-методологічного забезпечення, яке б відповідало сфері діяльності таких установ, але при цьому дотримувалося єдиної системи відображення всіх операцій 6 бухгалтерському обліку. До того ж слід брати до уваги і те, щзо сьогодні відбувається масштабне реформування бюджетного обліку і приведення його до міжнародних стандартів. У статті розглядаються сучасні проблеми обліку бюджетних установ, які передбачені міжнародними стандартами, його роль у достатньому забезпеченні та контролі иілеспрямованого й ефективного використання фінансових ресурсів. Визначаються проблеми та необхідність розроблення належного методичного забезпечення та узгодження з нормами чинного законодавства.

Ключові слова: бухгалтерський облік, фінанси, фінансові ресурси, бюджетні установи, міжнародні стандарти обліку, контроль, фінансова дисиипліна.

При организачии деятельности бюджетных учреждений возникает необходимость в достоверном и своевременном учете движения средств, которые им выделяются из государственного бюджета. Это предусматривает разработку теоретико-методологического обеспечения, которое бы соответствовало сфере деятельности таких учреждений, но при этом соблюдало единую систему отображения всех операций в бухгалтерском учете. К тому же следует принимать во внимание и то, что сегодня происходит масштабное реформирование бюджетного учета и приведение его к международным стандартам. В статье рассматриваются современные проблемы учета бюджетных учреждений, которые предусмотрены международными стандартами, его роль в достаточном обеспечении и контроле челенаправленного и эффективного использования финансовых ресурсов. Определяются проблемы и необходимость разработки надлежащего методического обеспечения и увязки с нормами действующего законодательства.

Ключевые слова: бухгалтерский учет, финансы, финансовые ресурсы, бюджетные учреждения, международные стандарты учета, контроль, финансовая дисииплина.

Taking into account the fact that the country's economy is moving through European integration and carrying out large-scale changes in this system, it be-comes necessary to study its individual directions and areas of activity. Particular attention should be paid to the management of the finances of public sector institutions. A significant part of the state budget funds is used for their maintenance, and taking into account the current financial situation, the issues of their rational use are key in achieving further stabilization and development of the economy and the implementation of key state tasks. The activities of budgetary institutions are fundamentally different from the activities of enterprises in other sectors of the economy. The financial component and control of funds are the main task of ensuring the efficiency of the activities of budgetary institutions, which can be successfully dealt with through accounting. When organizing their activities, there is a need for reliable and timely accounting of the movement of funds that are allocated to them from the state budget and to ensure control over their intended use. One of the most reliable sources of information on the movement of funds is accounting and therefore its appropriate methodological support should be aimed at developing the principles that are set out in the norms of the current legislation and the developed accounting standards for the public sector, but taking into account the specifics of the activities of each structure. Fundamental changes are taking place in the national accounting system, which are associated with its transition to international standards. The corresponding theoretical substantiation of this issue makes it possible to determine the extent of its research and identify unresolved problems that must be subsequently taken into account when improving the methodological base. The article discusses modern problems of accounting for budgetary institutions, which are provided for by international standards, its role in sufficient provision and control of targeted and effective use of financial resources. The problems and the need to develop appropriate methodological support and linkage with the norms of the current legislation are determined.

Key words: accounting, finance, financial resources, budgetary institutions, international accounting standards, control, financial discipline. 
Постановка проблеми. Економічний розвиток країни проходить шлях глибоких трансформаційних змін, що пов'язано з іiі інтеграцію в європейський простір та необхідністю запровадження міжнародних стандартів в усі сфери економіки країни. Не виключенням $є$ і система бухгалтерського обліку у бюджетних установах, яка нині переходить на міжнародні стандарти і потребує певного теоретико-методологічного обгрунтування та розроблення принципів іiі реалізації.

Бухгалтерський облік у бюджетних установах має певні особливості, що пов'язані зі сферою діяльності цих установ та джерелами їх фінансування.

Одним із найважливіших завдань бухгалтерського обліку в бюджетних установах є досягнення ефективності управління фінансовими ресурсами. Це забезпечує виконання низки заходів, пов'язаних зі складанням кошторисів, їх затвердженням, вчасним витребуванням коштів, цілеспрямованим їх використанням, контролем за дотриманням норм чинного законодавства під час витрачання коштів, гарантуванням належного утримання майна, дбайливим розподілом запасів тощо.

Таким чином, бухгалтерський облік є одним із джерел ефективного управління фінансовими ресурсами та гарантовано забезпечує належне виконання покладених на бюджетні установи завдань.

Аналіз останніх досліджень та публікацій. Питанням організації бухгалтерського обліку у бюджетних установах у науковій літературі приділяється досить значна увага. У роботах таких учених, як Т.М. Писаренко [1], В.А. Мазур, Н.Ф. Яремчук та Ю.В. Дубовий [2], Т.I. Хомуляк [3], Г.В. Янчук, О.І. Черешнева [4], Г.В. Рак [7], Т.Г. Китайчук Т.Г. [8] та інші, піднімаються актуальні питання реформування системи обліку та переходу до міжнародних стандартів. Одночасно слід зазначити, що удосконалення цих питань не тільки буде сприяти належній організації обліку в бюджетних установах, а й створить умови ефективного управління державними фінансами, уникнення проблем недофінансування та контролю використання бюджетних коштів. Актуальним питанням є подальше розроблення методологічного забезпечення системи обліку в бюджетних установах, яку можливо розробити на підставі глибокого аналізу цієї проблеми.

Мета статті полягає у дослідженні та визначенні ролі бухгалтерського обліку у сфері управління фінансовими ресурсами, що виділяються бюджетним установам на організацію своєї діяльності в межах визначеного фінансування, та формуванні належної інформаційної єдиної бази даних про рух коштів за новими стандартами обліку.

Виклад основного матеріалу. Організація діяльності бюджетних установ здійснюється в межах визначеного та затвердженого кошторису, що потребує постійного дотримання та ув'язки обсягів із термінами надходження фінансових ресурсів на відповідний період. Нагальною проблемою сьогодення в системі організації фінансування бюджетних установ є необхідність забезпечення ефективного використання бю- джетних коштів, що потребує насамперед фінансової дисципліни та належної організації обліку. Бюджетні установи в процесі діяльності співпрацюють 3 різними установами та підприємствами як державного, так i недержавного сектору, що досить часто призводить до невідповідності та складності відображення господарських операцій у бухгалтерському обліку. У процесі реформування необхідно досягти єдиних підходів та узгодженості відображення операцій, їх відповідності кодам економічної класифікації.

Як відзначає Т.М. Писаренко, «економічні перетворення, що відбуваються в Україні, завжди потребують перегляду основних положень побудови вітчизняної облікової системи. Як завжди, ми вивчаємо досвід економічно розвинених країн, де облік є одним із головних важелів в управлінні господарським суб'єктом. Особливої уваги заслуговують зміни у бюджетному секторі економіки, адже саме бюджетні установи часто виконують функції, які не можуть виконувати підприємства, основною метою діяльності яких є отримання прибутку» [1].

В.А. Мазур, Н.Ф. Яремчук та Ю.В. Дубовий вказують на необхідність постійного удосконалення обліку бюджетних установ та відзначають, що «дослідження теоретичних аспектів ведення бухгалтерського обліку в бю-джетних установах дає можливість зрозуміти основні принципи фінансової діяльності організацій державного сектору» [2, с. 24].

Незважаючи на досить значну увагу вчених до питань обліку в бюджетних установах та беручи до уваги ті зміни, які відбуваються сьогодні в економіці країни, проблеми потребують подальшого дослідження та вдосконалення облікової політики, а на іiі базі - забезпечення належної організації управління фінансами та розроблення єдиної методологічної бази.

Ще на початку запровадження міжнародних стандартів обліку у бюджетному секторі T.I. Хомуляк відзначав: «Перехід від національних до міжнародних стандартів фінансової звітності в умовах глобалізації повинен бути поступовим і цілеспрямованим процесом. Усунення невідповідності вітчизняної облікової системи повинно відбуватися разом із потребами економіки без порушення цілісності всієї системи. Впровадження Міжнародних стандартів фінансової звітності для державного сектору (МСФЗДС) вимагає узгодження їх норм із чинною національною законодавчою базою, а створення законодавчих та організаційних передумов їх запровадження слід врегульовувати порядком застосування останніх» [3, с. 80].

Питання необхідності належного методологічного забезпечення ведення бухгалтерського обліку в умовах переходу на міжнародні стандарти піднімаються і в дослідженні Г.В. Янчук та О.I. Черешневої. Вони звертають увагу на те, що бюджетні установи мають різні завдання, призначення та відомчу підлеглість, що обов'язково необхідно брати до уваги у сфері визначення напрямів їхньої облікової політики. У своєму дослідженні вони відзначають, що «основними недоліками переходу бухгалтерського обліку до єдиної методології 
відображення операцій є неповне врахування специфіки діяльності окремих установ та особливостей обліку в різних галузях економіки, що створює надлишкове накопичення дублюючої інформації. Для вирішення цієї проблеми головним розпорядникам коштів слід встановити терміни для найшвидшого повного приведення внутрішніх установчих наказів розпорядників коштів до єдиної методології. Крім того, державі слід більше уваги приділити інформаційній забезпеченості нововведень, створити достатню інформаційну базу щодо практичного застосування змін у бухгалтерському обліку, що в майбутньому зменшить ризики бюджетних та фінансових правопорушень» [4, с. 108].

Належне інформаційне забезпечення та побудова сучасної інформаційної системи дасть змогу не тільки вчасно відображати всі операції, а й скоординувати управління фінансами [5, с. 147; 6, с. 685]. Добре сформована інформаційна система та наявність сучасного програмного забезпечення в бюджетних установах буде гарантувати постійний контроль за використанням фінансових ресурсів та неухильне дотримання фінансової дисципліни.

Для забезпечення контролю цільового використання та ефективного управління державними фінансами та виконання бюджету всі бюджетні установи фінансуються через органи Державного казначейства, які забезпечують контроль та дотримання цілеспрямованого використання коштів вже під час здійснення операцій, пов'язаних із використанням коштів, та сприяють недопущенню будь-яких відхилень. А як відзначає Г.В. Рак, «особливості діяльності бюджетних установ у системі казначейського обслуговування бюджету визначають доцільність продовження розвитку теорії та практики ведення бухгалтерського обліку у бюджетній сфері на основі врахування облікових та контрольних вимог до процесу кошторисного фінансування бюджетних установ» $[7$, с. 161].
Бухгалтерський облік стає ключовим та центральним ланцюгом у системі управління фінансами, який можна відобразити таким чином:

За такої послідовності вирішуються питання управління фінансами бюджетних установ, а інформація, яка формується та накопичується в регістрах бухгалтерського обліку, є вихідною для прийняття обгрунтованих управлінських рішень, що сприяють реалізації стратегічних та поточних завдань установ бюджетного сектору.

Як зазначає Т.Г. Китайчук, «виходячи з означених позицій, слід відзначити, що реформування системи обліку сприятиме прозорості управління державними фінансами; удосконаленню системи фінансового контролю та ефективному використанню фінансових ресурсів; впровадженню національних стандартів бухгалтерського обліку та звітності на основі загальноприйнятих міжнародних стандартів; підвищенню статусу та ролі обліково-економічного персоналу» [8, с. 114].

Нині проведено вже значну роботу у сфері реформування бухгалтерського обліку та фінансової звітності в державному секторі економіки, яка була визначена в «Стратегії модернізації системи бухгалтерського обліку в державному секторі на 2007-2015 роки». Зокрема, розроблені та введені в дію національні положення (стандарти) бухгалтерського обліку, запроваджено новий план рахунків в державному секторі, розроблено та впроваджено форми фінансової звітності та методику ïх заповнення, прийнято положення про бухгалтерську службу [9]. Тобто основні напрями, що визначалися стратегією, реалізовані. У 2018 році кабінет міністрів України схвалив «Стратегію модернізації системи бухгалтерського обліку та фінансової звітності в державному секторі на період до 2025 року». Метою цієї Стратегії є підвищення якості, повноти та достовірності даних фінансової звітності, на основі яких приймаються управлінські рішення у сфері державних фінан-

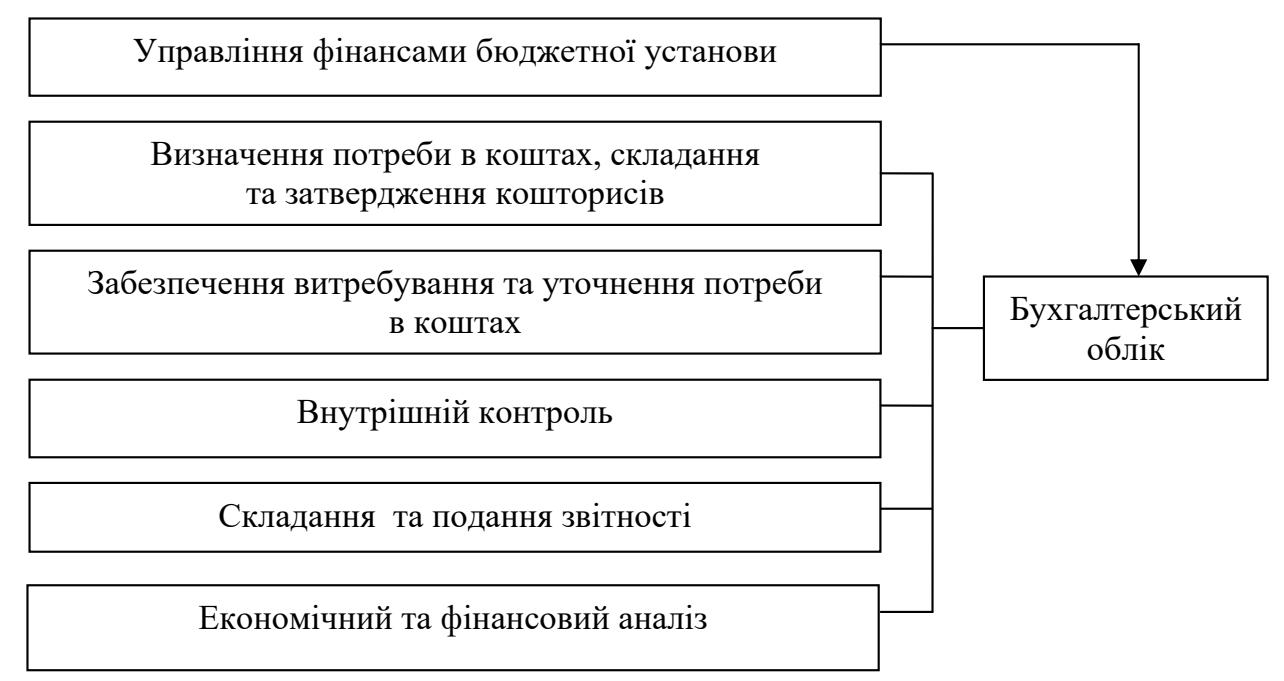

Рис. 1. Процес управління фінансами бюджетних установ

Джерело: запропоновано автором 
сів [10]. Цей етап ставить нові завдання в організації системи бухгалтерського обліку державного сектору, що обов'язково повинно бути враховано бюджетними установами у своїй діяльності.

Всі зазначені проблеми слід врахувати під час розроблення облікової політики бюджетних установ та забезпечення відповідності їх цілям та меті. Процес реформування системи бухгалтерського обліку в бюджетних установах триває, а тому нагальним питанням $\epsilon$ постановка нових завдань та шляхів їх реалізації, що обов'язково потребує додаткового фінансування цих заходів і врахування їх під час складання кошторисів на відповідний період.
Висновки. У результаті проведеного дослідження можна відзначити, що ті заходи, які сьогодні реалізуються в бюджетних установах у сфері реформування бухгалтерського обліку, передбачають побудову єдиної системи відображення та накопичення інформації. Їх реалізація спрямована саме на контроль за дотриманням прозорості та цільового використання коштів, що їм виділяються 3 державного бюджету. Ситуація в економіці країни ще не стабілізувалася, це вказує на те, що в подальшому розміри фінансування бюджетних установ можуть змінитися залежно від стану наповнення бюджету, що буде створювати додаткове навантаження на систему управління.

\section{Список літератури:}

1. Писаренко Т.М. Особливості організації обліку у бюджетних установах. Економічні науки. Сер.: Облік $i$ фінанси. 2013. Вип. 10(2). с. 193-202.

2. Мазур В.А., Яремчук Н.Ф., Дубовий Ю.В. Стан та перспективи розвитку бухгалтерського обліку в бюджетних установах відповідно до сучасних вимог міжнародних стандартів. Економіка. Фінанси. Менеджмент: актуальні питання науки і практики. 2017. № 9. С. 23-32.

3. Хомуляк Т.I. Особливості обліку у бюджетних установах в умовах сьогодення. Вісник Житомирського державного технологічного університету. Серія: Економічні науки. 2014. № 2. с. 75-81

4. Янчук Г.В., Черешневий O.I. Модернізація системи бухгалтерського обліку бюджетної сфери як необхідність ефективного управління державними фінансами. Економіка. Фінанси. Менеджмент: актуальні питання науки і практики. 2017. № 1. с. 103-112.

5. Гончаренко Н.Г. Роль економічної інформації в прийнятті ефективних управлінських рішень. Науковий вісник Херсонського державного університету (серія «Економічні науки»). 2018. № 28-2. С. $145-148$.

6. Гончаренко Н.Г. Роль та особливості організації бухгалтерського обліку в бюджетних установах. Глобальні принципи фінансового, облікового та аналітичного забезпечення аграрного сектора економіки : матеріали Міжнародної науково-практичної конференції, м. Харків, 9 листопада. 2018 р. Харків, 2018. С. 42-45.

7. Рак Г.В. Кошторисне фінансування бюджетних установ у системі казначейського обслуговування бюджету. Економічний аналіз. 2014. Т. 17. № 1. С. 160-166.

8. Китайчук Т.Г. Модернізація бухгалтерського обліку в державному секторі: проблеми перехідного періоду. Економіка. Фінанси. Менеджмент: актуальні питання науки і практики. 2017. № 7. С. 106-117.

9. Стратегія модернізації системи бухгалтерського обліку в державному секторі на 2007-2015 роки: Постанова Кабінету міністрів України від 16 січня 2007 р. № 34. URL: https://zakon.rada.gov.ua/laws/show/34-2007 (дата звернення 18.12.2020).

10. Про схвалення Стратегії модернізації системи бухгалтерського обліку та фінансової звітності в державному секторі на період до 2025 року: Розпорядження Кабінету міністрів України від 20 червня 2018 p. № 437-p. URL: https://zakon.rada.gov.ua/laws/show/437-2018 (дата звернення 18.12.2020).

\section{References:}

1. Pysarenko T.M. (2013) Osoblyvosti orghanizaciji obliku u bjudzhetnykh ustanovakh [Features of the organization of accounting in budgetary institutions]. Economic sciences. Ser.: Accounting and Finance, vol. 10 (2), pp. $193-202$.

2. Mazur V.A., Jaremchuk N.F., Dubovyj Ju.V. (2017) Stan ta perspektyvy rozvytku bukhghaltersjkogho obliku $\mathrm{v}$ bjudzhetnykh ustanovakh vidpovidno do suchasnykh vymogh mizhnarodnykh standartiv [Status and prospects of accounting development in budgetary institutions in accordance with modern requirements of international standards]. Economy. Finances. Management: current issues of science and practice, no. 9, pp. 23-32.

3. Khomuljak T.I. (2014) Osoblyvosti obliku u bjudzhetnykh ustanovakh v umovakh sjoghodennja [Features of accounting in budgetary institutions in today's conditions]. Bulletin of Zhytomyr State Technological University. Series: Economic Sciences, no. 2, pp. 75-81.

4. Janchuk Gh.V., Chereshnevyj O.I. (2017) Modernizacija systemy bukhghaltersjkogho obliku bjudzhetnoji sfery jak neobkhidnistj efektyvnogho upravlinnja derzhavnymy finansamy [Modernization of the budget accounting system as a necessity of effective public finance management]. Economy. Finances. Management: current issues of science and practice, no. 1, pp. 103-112.

5. Goncharenko N.G. (2018) Rolj ekonomichnoji informaciji v pryjnjatti efektyvnykh upravlinsjkykh rishenj [The role of economic information in the adoption of effective government decisions]. Scientific Bulletin of Kherson State University (series "Economic Sciences"), no. 28-2, pp. 145-148.

6. Honcharenko N.G. (2018) Rolj ta osoblyvosti orghanizaciji bukhghal-tersjkogho obliku v bjudzhetnykh ustanovakh [The role and features of the organization of accounting in budgetary institutions]. Global principles of financial, accounting and analytical support of the agricultural sector of the economy (Ukraina, Kharkiv, November 9, 2018), Kharkiv, pp. $42-45$. 
7. Rak Gh. V. (2014) Koshtorysne finansuvannja bjudzhetnykh ustanov u systemi kaznachejsjkogho obslughovuvannja bjudzhetu [Estimated financing of budgetary institutions in the system of treasury budget service]. Economic analysis, vol. 17, no. 1, pp. 160-166.

8. Kytajchuk T.Gh. (2017) Modernizacija bukhghaltersjkogho obliku v derzhavnomu sektori: problemy perekhidnogho periodu [Modernization of ac-counting in the public sector: problems of the transition period]. Economy. Finances. Management: current issues of science and practice, no. 7, pp. 106-117.

9. Strateghija modernizaciji systemy bukhghaltersjkogho obliku v derzhavnomu sektori na 2007-2015 roky: Postanova Kabinetu ministriv Ukrajiny vid 16 sichnja 2007 r. № 34 [Strategy for modernization of the accounting system in the public sector for 2007-2015: Resolution of the Cabinet of Ministers of Ukraine of January 16, 2007 № 34.]. Available at: https://zakon.rada.gov.ua/laws/show/34-2007 (accessed 18 December 2020).

10. Pro skhvalennja Strateghiji modernizaciji systemy bukhghaltersjkogho obliku ta finansovoji zvitnosti v derzhavnomu sektori na period do 2025 roku: Rozporjadzhennja Kabinetu ministriv Ukrajiny vid 20 chervnja 2018 r. № 437-r [On approval of the Strategy for modernization of the accounting and financial reporting system in the public sector for the period up to 2025: Order of the Cabinet of Ministers of Ukraine of June 20, 2018 № 437-r]. Available at: https://zakon.rada.gov.ua/laws/show/437-2018 (accessed 18 December 2020). 